Research Article

\title{
Understandings on the Performance of Concrete-Filled Steel Tube with Different Kinds of Concrete Infill
}

\author{
K. B. Manikandan $(1)$ and C. Umarani $(i D)$ \\ Division of Structural Engineering, CEG, Anna University, Chennai 600025, India \\ Correspondence should be addressed to K. B. Manikandan; kbmanikandan.str@gmail.com
}

Received 14 December 2020; Revised 27 March 2021; Accepted 21 April 2021; Published 4 May 2021

Academic Editor: Francesco Colangelo

Copyright (c) 2021 K. B. Manikandan and C. Umarani. This is an open access article distributed under the Creative Commons Attribution License, which permits unrestricted use, distribution, and reproduction in any medium, provided the original work is properly cited.

\begin{abstract}
In recent years, concrete-filled steel tube (CFST) has gained attention in the construction sectors due to its unique static and earthquake resistant properties. The steel-concrete composite member is formed by filling the concrete inside the hollow steel tube of various shapes. The experimental and numerical investigations were carried out for CFST members filled with different types of concrete of the same grade. The types of concrete used for this study are conventional concrete, steel fiber-reinforced concrete, geopolymer concrete, and expansive concrete, respectively. The concretes were cast in the form of cubes followed by curing underwater and self-curing conditions. The specimens cured for 7 and 28 days of age were subjected to axial compressive strength testing. The effect of curing conditions on the strength of concrete was evaluated by comparing the obtained results. Self-curing, the only possible way of curing infilled concrete in the case of CFST columns, was found to have no influence on the strength of concrete, and the same curing method was adopted for the CFST columns tested in this study. A total of 24 CFST specimens were cast by different types of concrete infill, and their load carrying capacity under axial compression and their bond strength were determined through experimental investigations. The characteristic strengths measured for the CFST columns with different types of concrete infill were compared, and the results are presented. The analytical investigations were carried out by using Eurocode- 4 to predict the load-bearing capacity of CFST columns under axial compression. Finally, the load carrying capacities of CFST columns under axial compression obtained through experimental and simulation studies were compared and the results are presented.
\end{abstract}

\section{Introduction}

A structural member composed of two or more dissimilar materials is known as composite members. Since structural composites exhibit multiple properties, they have superior properties to the individual elements. The steel-concrete composite member is one of the most widely used composite members in the structural engineering industry [1]. Though concrete performs well under compression, they have relatively low resistance towards tension forces. In contrast, steel is very strong in tension and even used in smaller quantities. The combination of steel-concrete composite members utilizes the concrete's compressive strength and steel's resistance to tension thereby making it an efficient candidate in the construction industry.
Concrete-filled steel tube (CFST) based composite structures use the benefits of both hollow structural steel and concrete core. The composite action between the constituent elements present in the CFST column enhances its structural system behavior. Due to the high strength, high ductility, and large energy absorption capacity, CFST members retain good resistance towards vibrations due to static and earthquakes. During an axial compression load, concrete inside the steel tube is confined and thereby improves the load resistance and ductility of CFST members. CFST materials fail more favorably by a ductile fracture mechanism due to the high shear capacity of concrete-filled steel tubular members. Moreover, the steel tube serves as a permanent framework for the well-distributed concrete reinforcements. Since the approach is cost-effective, they substantially 
contribute to the speed of the erection work. The inward local buckling observed in bare steel hollow columns is circumvented by employing concrete-filled steel tubes [2]. This specific feature in CFST members offers high loadbearing capacity than the bare steel hollow columns.

As CFST columns require only a small cross section to withstand the load, they are valued as promising material by civil engineers and architects. The adequate confinement imposed by steel to the infilled concrete delays the local buckling of the steel tube in CFST columns. This beneficial feature makes concrete-filled steel tubes a suitable candidate in various structural applications such as column supported offshore platforms, buildings, columns of water tanks, bridge piers, and piles in both seismic and wind prone zones. A schematic diagram of a concrete-filled steel tube is shown in Figure 1.

Prevalent theoretical study and laboratory trials have revealed the mechanical properties of CFST columns, by Han et al. [3-7], Guneyisi et al. [8], Abed et al. [9], and Tao et al. [10-12] and formed a broad theoretical and specification system for CFST columns. The structural performance of a loaded CFST section can be explained through concrete microcracking theories and the Poisson effects of the constituent materials. Since the Poisson ratio of concrete is smaller than steel, the separation between steel and concrete occurs during the initial stages of the loading. If the bond stress between the steel-concrete interface is sufficient to restrict the separation, therefore, lateral stress is developed in the outer surface of the concrete core. Since the effect of bond stress is small, the impact of these interactions is usually neglected. Hence, both steel and concrete in the CFST columns are assumed to exhibit combined uniaxial stress. The ductility of the column decreases with the concrete infill (core concrete) strength and increases for higher $D / t$ ratio but for lower $D / t$ ratio the converse is true. An increase in the $D / t$ ratio reduces the CFST member's stiffness and axial strength of the material. This is due to the decreased confinement of the concrete in the steel tube [9]. The circular CFST columns perform better than the square section, and the square section has a stronger bearing capacity than the rectangular section. Due to the enhanced confinement effect, the circular section columns outperform the square and rectangular sections. The load-bearing capacity of the CFST columns improves with the grade of the concrete [10]. The bond strength and compressive strength of the CFST columns can be improved by the lower replacement using fly ash with cement. Achieving similar beneficial effects through higher replacement with fly ash requires a relatively long time [13]. Types of concrete such geopolymer concrete, steel fiber-reinforced concrete, expansive concrete, and self-compacting concrete are recognized as an environmentally friendly, better performing alternative material to conventional concrete. Geopolymer concrete is formed by reacting aluminate and silicate bearing materials with a caustic activator. Usually, unutilized or waste materials such as slag from iron and metal production or fly ash are used, which helps lead to a cleaner environment. Geopolymer concrete-filled steel column exhibits better strength compared to the conventional CFST columns. When it is exposed to elevated temperatures, it has lower strength loss than other columns [14]. Fiber reinforcement concrete is an amalgamated material entailing of cement paste, mortar, or concrete with fibers made of glass, plastic, carbon, asbestos, or steel. Such concrete may be suitable where high tensile strength and reduced cracking are looked for. Fibers when used in concrete are very useful in the development of compressive, split tensile, and flexural strengths of concrete [15]. Expansive concrete or shrinkage-compensating concrete is a type of concrete in which expansion if restrained induces compressive stresses which approximately offset tensile stresses in the concrete induced by drying. The microexpansive concrete fill inside the steel tube can not only compensate for the conventional shrinkage but also produces the prestress in the core concrete [Cheng et al.].

In recent years, the studies on CFST columns are focused on high strength concrete, thin-walled steel tubes, the effect of confinement, behavior of slender columns, and the interface bond behavior.

Though the recent works of literature emphasizing the recent technological advancements of CFST columns are available, an informational insight on the behavior of concrete-filled steel tube having different types of concrete infill is still lacking. Hence, in the current study, an attempt has been made to understand the behavior of different types of concrete-filled steel tube of the same grade through an experimental and theoretical approach.

\section{Materials and Methods}

In this study, the mechanical characterization was performed for different types of concrete infill in the steel tube to gain insight into the material behavior under axial loading. The methodology, materials, and characterization techniques used are outlined briefly below.

The fabrication and casting of CFST members were carried out by using four different types of concretes, namely, (i) conventional concrete, (ii) steel fiber-reinforced concrete, (iii) geopolymer concrete, and (iv) expansive concrete. Initially, two sets of cube specimens were cast. Followed by this, one set of cubes were water cured, and the rest were subjected to self-curing by using Concure WB30 (Figure 2). In the case of geopolymer concrete cubes, an ambient curing method was adopted. All the cured cube specimens were tested for compressive strength at the age of 28 days. The obtained results were used for the validation of samples prepared by the self-curing method.

2.1. Mix Design. The materials were tested and mix design for the proportioning of ingredients of concrete was carried out as per IS 10262:2009 [16]. The mix proportion was done in such a way that all types of concrete have almost the same (with acceptable variation) compressive strength which could be achieved after making several trial mixes and the proportions for one meter cube of concrete are listed in Table 1 . The conventional concrete of grade M-25 was used as an ingredient with no mineral or chemical admixture. An 


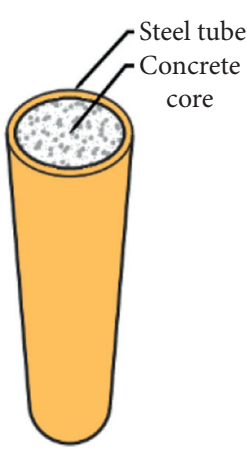

(a)

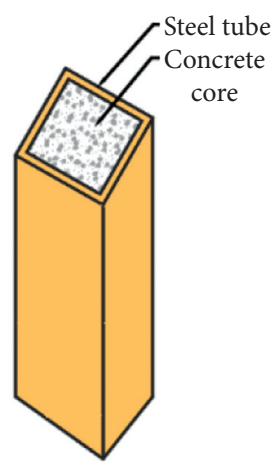

(b)

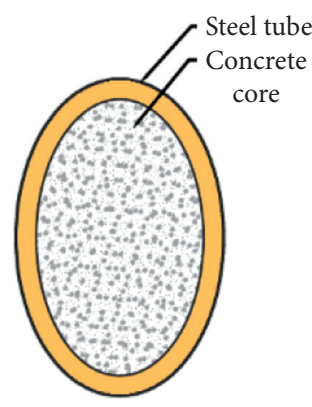

(c)

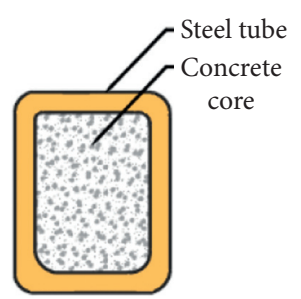

(d)

FIgURE 1: Concrete-filled steel tubes.

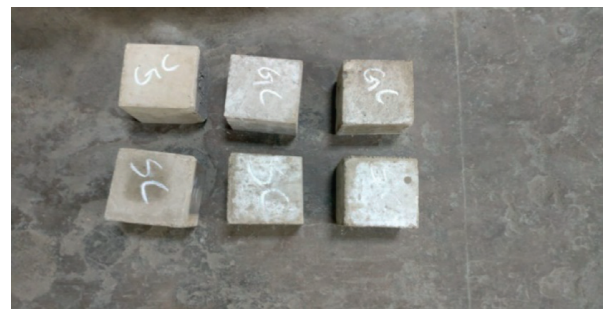

Figure 2: Self-curing of concrete cubes.

TABLE 1: Details of mix proportions.

\begin{tabular}{|c|c|c|c|c|c|c|}
\hline \multirow[b]{2}{*}{ Type of concrete } & \multirow[b]{2}{*}{$\begin{array}{l}\text { Cement } \\
(\mathrm{kg})\end{array}$} & \multirow[b]{2}{*}{$\begin{array}{l}\text { Fine aggregate } \\
(\mathrm{kg})\end{array}$} & \multicolumn{2}{|c|}{ Coarse aggregate $(\mathrm{kg})$} & \multirow[b]{2}{*}{$\begin{array}{l}\text { Water } \\
\text { (lit) }\end{array}$} & \multirow[b]{2}{*}{ Other ingredients } \\
\hline & & & $\begin{array}{c}20 \mathrm{~mm} \\
(60 \%)\end{array}$ & $\begin{array}{c}12.5 \mathrm{~mm} \\
(40 \%)\end{array}$ & & \\
\hline Conventional concrete(CC) & 437.78 & 650.25 & 661.5 & 441 & 197 & Nil \\
\hline $\begin{array}{l}\text { Steel fiber-reinforced concrete } \\
\text { (SC) }\end{array}$ & 437.78 & 650.25 & 661.5 & 441 & 197 & $\begin{array}{c}\text { Hook type steel fibers } \\
0.75 \% \text { by volume of } \\
\text { concrete }(18 \mathrm{~kg})\end{array}$ \\
\hline Geopolymer concrete (GC) & Nil & 650.25 & 661.5 & 441 & Nil & $\begin{array}{l}\text { FA and GGBS each } 50 \% \\
\text { by weight of cement, } \\
5 \mathrm{M} \mathrm{NaOH} \text { and sodium } \\
\text { silicate (197 litres) }\end{array}$ \\
\hline Expansive cement (EC) & 437.78 & 650.25 & 661.5 & 441 & 197 & $\begin{array}{c}\text { Cebex 100, } 0.45 \% \\
\text { by weight of cement }\end{array}$ \\
\hline
\end{tabular}

OPC cement of grade 53 was used for this purpose. The steel fiber-reinforced concrete of M-25 grade was used with no additives such as mineral or chemical admixture. The cement used was OPC of grade 53. An optimal percentage $(0.75 \%)$ of steel fibers was added in steel fiber-reinforced concrete. The geopolymer concrete of M-25 grade was used. The fly ash and ground granulated blast furnace slag of ratio $50 \%$ were used in geopolymer concrete. Along with sodium silicate, sodium hydroxide of $5 \mathrm{M} \mathrm{NaOH}$ was used as an alkali activator solution. The expansive concrete of M-25 grade was used in this study. To avoid shrinkage and to achieve a positive expansion in the concrete, a chemical admixture (expansive agent) Fosroc Cebex 100 was used in this study. The dosage used was $0.45 \%$ by weight of cement.

For the determination of load carrying capacity under axial compression and bond strength, the CFST columns of dimensions $750 \mathrm{~mm} \times 75 \mathrm{~mm} x 1.6 \mathrm{~mm}$ (length $x$ diameter $x$ thickness) and $500 \mathrm{~mm} \times 88 \mathrm{~mm} \times 4 \mathrm{~mm}$ were used, respectively. For bond strength testing, an air gap of $50 \mathrm{~mm}$ was provided at the bottom of the CFST specimens to facilitate the slip of the concrete core. The cast and self-cured CFST columns are shown in Figure 3. The experimental test results are tabulated, and the graphs are plotted.

\section{Experimental and Theoretical Investigation}

The cubes and CFST specimens required for the study were cast, cured, and tested for their load carrying capacity under axial compression and bond strength. The experimental test results are tabulated and the graphs are plotted. Similarly, theoretical investigations were carried out using Euro Code -4 and the results are discussed. 


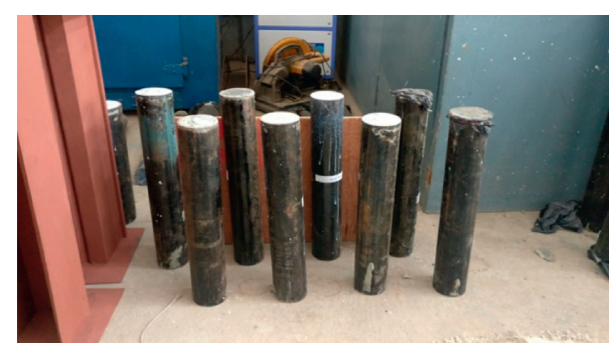

FIgURE 3: CFST columns under self-curing.

3.1. Validation of Self-Curing Method. A low viscosity membrane type curing compound (Concure WB 30) was applied to all the cube specimens externally on the surface. The cube specimens of conventional concrete, steel fiberreinforced concrete, and expansive concrete cured by water curing and self-curing were tested for their axial compressive strength at the age of 7 days and 28 days in compression testing machine to determine the characteristic compressive strength of concrete which is shown in Figure 4. For geopolymer concrete ambient curing was adopted.

The details of the cube specimens used for validation of curing method are presented in Table 2.

The average values of the characteristic compressive strength of different types of concrete under water curing and self-curing are presented in Table 3. The compressive strength of conventional concrete, steel fiber-reinforced concrete, geopolymer concrete, and expansive concrete cubes cured under water curing and self-curing/ambient curing at 28 days is presented in Figure 5.

Therefore, it is inferred that there is not much difference in the compressive strength of different types of concrete cubes at 28 days when cured under water curing and selfcuring. All types of concrete cubes cured under self-curing/ ambient curing fall within the acceptable criteria. Hence, in the present study, the method of self-curing was adopted for CFST columns using the curing agent concure WB 30.

3.2. Test to Determine the Bond and Axial Compression Strength. The push-out test and axial compression tests were carried out for CFST columns to determine their bond strength. The experimental setup for the push-out test and axial compression test are as shown in Figures 6 and 7. The details of CFST column specimens used to find out bond strength and axial compression strength are shown in Table 4 . The schematic sketch showing the experimental setup for the bond strength test and axial compression test are shown in Figure 6.

The CFST column to be tested for bond strength and axial compression test was placed in the loading frame with the hydraulic jack capacity of $1000 \mathrm{kN}$. The loading arrangement was done in such a way that when the load is applied through hydraulic jack, only the concrete core is loaded to push the core concrete out from the CFST specimen. This was ensured by providing a steel plate of diameter a little lesser than the inner diameter of the CFST column. The slip of the concrete infill was given in increments and the corresponding load taken by the CFST column was read by the load cell which was placed above the steel plate as shown in Figure 7. The experimental values (average) of the push-out test are presented in Table 5. For axial compression test, columns with strain gauge fixed at the mid-height was placed in the loading frame. For the given load increment, the strain value was read by the strain indicator to which the strain gauge was attached and the mid-height deflection was read by the dial gauge placed at the level of mid-height of the column. The experimental test readings of axial compression test are presented in Table 6.

\subsection{Estimation of Axial Load Carrying Capacity Using Euro} Code 4. The axial load carrying capacity for the CFST columns were estimated using Eurocode-4. Comparison of the estimated values and the experimental results was made. Table 7 shows the observed axial load from experiment, predicted axial load using EC4, and percentage variation between the experimental and predicted values. According to Eurocode-4, the axial load carrying capacity of CFST circular column is given by

$$
N_{\mathrm{pl}, \mathrm{Rd}}=\eta_{a} A_{a} f_{y}+A_{c} f_{\mathrm{cd}}\left(1+\left(\frac{\eta_{c} t f_{y}}{D * f_{\mathrm{ck}}}\right)\right),
$$

where $\eta_{\mathrm{a}}, \eta_{\mathrm{c}}$ are the confinement ratios for steel and concrete, respectively, $A_{\mathrm{a}}, A_{\mathrm{c}}$ are area of steel and area of concrete, respectively, $D$ is the outer diameter of steel tube, $T$ is the thickness of the steel tube, $f_{\mathrm{y}}$ is the yield strength of steel, and $f_{\mathrm{ck}}$ is the characteristic compressive strength of concrete.

The confinement ratio of steel and concrete are based on relative slenderness $(\lambda)$. If $\lambda>0.5$, the effect of confinement is negligible and can be neglected.

$$
\begin{aligned}
\eta_{a} & =\operatorname{Min}(0.25(3+2 \lambda), 1.0), \\
\eta_{c} & =\operatorname{Max}\left(\left(4.9-18.5 \lambda+17 \lambda^{2}\right), 0\right), \\
\lambda & =\sqrt{\frac{N_{\mathrm{pl}, \mathrm{Rk}}}{N_{\mathrm{cr}}}}
\end{aligned}
$$

where $N_{\mathrm{pl}, \mathrm{Rk}}$ is the characteristic plastic resistance of the cross section of CSFT.

$$
N_{\mathrm{pl}, \mathrm{rk}}=A_{a} f_{y}+A_{c} f_{\mathrm{ck}}
$$

where $N_{\mathrm{cr}}$ is the elastic critical Euler's buckling resistance.

$$
N_{\mathrm{cr}}=\frac{\pi^{2} \mathrm{EI}_{\mathrm{eff}}}{L_{\mathrm{eff}^{2}}}
$$

where $\mathrm{EI}_{\text {eff }}$ is the effective flexural rigidity of CFST column and $L_{\text {eff }}$ is the effective length of the CFST column.

$$
\mathrm{EI}_{\mathrm{eff}}=E_{a} I_{a}+0.6 E_{c} I_{c},
$$

where $E_{\mathrm{a}}$ is the modulus of elasticity of steel tube, $E_{\mathrm{c}}$ is the modulus of elasticity of concrete core, $I_{\mathrm{a}}$ is the moment of inertia of the steel section, and $I_{c}$ is the moment of inertia of the concrete core. 


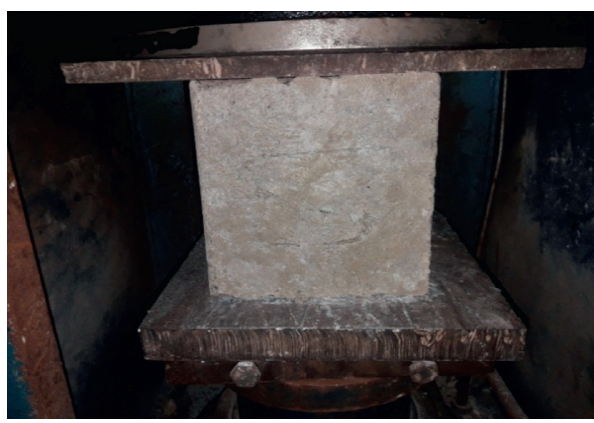

(a)

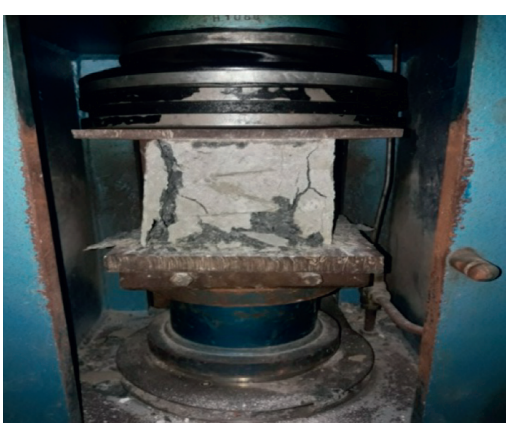

(b)

Figure 4: Testing of cubes for their compressive strength.

TABle 2: Details of cube specimens.

\begin{tabular}{|c|c|c|c|c|c|}
\hline \multirow{3}{*}{ Concrete type } & \multirow{3}{*}{ Specimen ID } & \multicolumn{4}{|c|}{ Number of specimens } \\
\hline & & \multicolumn{2}{|c|}{ Water curing } & \multicolumn{2}{|c|}{ Self-curing } \\
\hline & & 7 days & 28 days & 7 days & 28 days \\
\hline Conventional concrete & $\mathrm{CC}$ & 9 & 9 & 9 & 9 \\
\hline Steel fiber-reinforced concrete & SC & 9 & 9 & 9 & 9 \\
\hline Geopolymer concrete & GC & 9 & 9 & 9 & 9 \\
\hline Expansive concrete & EC & 9 & 9 & 9 & 9 \\
\hline
\end{tabular}

TABle 3: Compressive strength of concrete.

\begin{tabular}{|c|c|c|c|c|}
\hline \multirow{2}{*}{ Type of cube } & \multirow{2}{*}{ Age of testing (days) } & \multicolumn{2}{|c|}{ Average compressive strength of concrete $(\mathrm{MPa})$} & \multirow{2}{*}{$\%$ Difference } \\
\hline & & Water curing & Self-curing/ambient curing & \\
\hline \multirow{2}{*}{$\mathrm{CC}$} & 7 & 20.24 & 20.53 & 1.42 \\
\hline & 28 & 32.67 & 33.68 & 3.04 \\
\hline \multirow[b]{2}{*}{ SC } & 7 & 21.62 & 23.12 & 6.70 \\
\hline & 28 & 33.50 & 33.89 & 1.15 \\
\hline \multirow{2}{*}{ GC } & 7 & - & 23.73 & - \\
\hline & 28 & - & 33.89 & - \\
\hline \multirow{2}{*}{$\mathrm{EC}$} & 7 & 23.96 & 26.37 & 9.53 \\
\hline & 28 & 33.90 & 34.70 & 2.33 \\
\hline
\end{tabular}

$$
E_{c}=22\left(\frac{f_{c d}}{10}\right)^{0.3}
$$

where $f_{c d}$ is the design strength of concrete.

\section{Results and Discussion}

4.1. Bond Strength of CFST Columns. The bond strength of the CFST columns was determined from the Bond StrengthSlip curve plot as shown in Figure 8. The CCFST series columns failed at an average slip load of 20.25 tonnes with a slip of $1.2 \mathrm{~mm}$. For SCFST series column specimens, the failure was observed at a slip load of 17.35 tonnes with a slip of $1.5 \mathrm{~mm}$. In the case of GCFST and ECFST, the failure was observed at a slip load of 22.1 and 26.8 tonnes, respectively. The slip movement of GCFST and ECFST were found to be $2.3 \mathrm{~mm}$ and $0.8 \mathrm{~mm}$, respectively. The test results of all the CFST specimens are provided in Table 5. The push-out test results revealed that the highest bond strength was observed for CFST columns with expansive concrete. The reason for increased bond strength may be attributed to the shrinkage counteracting admixture used in expansive concrete. The slip loads measured at the constant slip of $0.5 \mathrm{~mm}$ for the various CFST columns are provided in Table 8 .

From the comparative studies of bond strength between CFST and ECFST, it can be inferred that the bond strength of CFST columns filled with steel fiber reinforcement, geopolymer, and expansive concrete at the slip of $0.5 \mathrm{~mm}$ differs with ECFST by $26.62 \%$ (lesser), 66.91\% (lesser), and 55.39\% (higher), respectively. In Figure 9, the variation of slip with load for various types of CFST column infills is shown.

4.2. Axial Compressive Strength of CFST Columns. The axial compressive strength of CFST columns filled with different types of concrete infills was investigated, and the results are discussed. The Load vs. deflection graph and axial load 


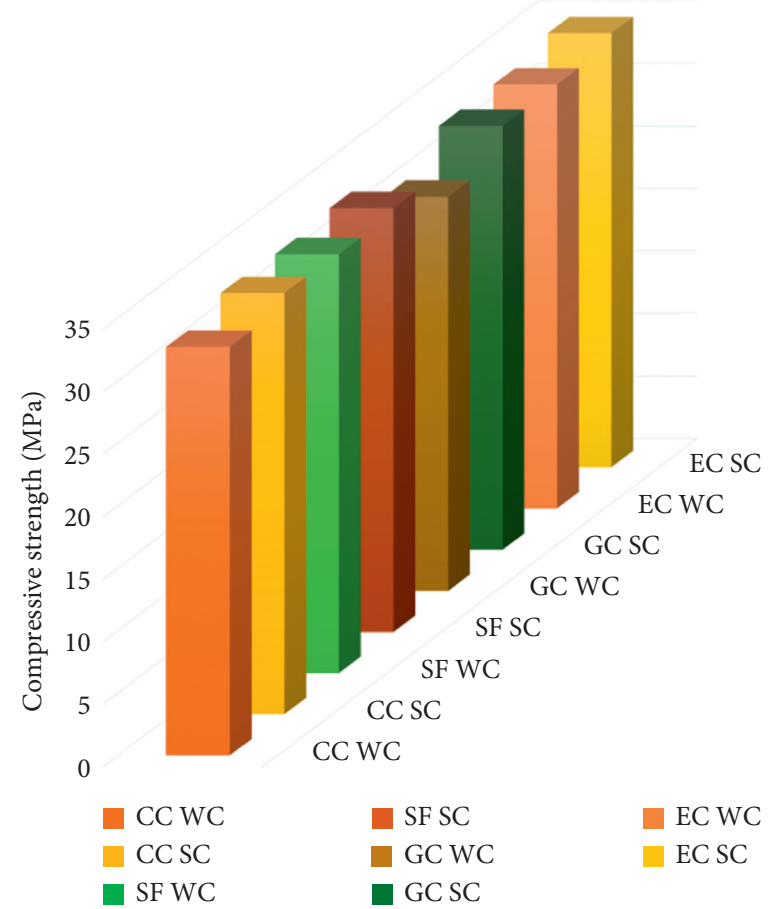

FIGURE 5: Compressive strength of concrete cubes at $28^{\text {th }}$ day.

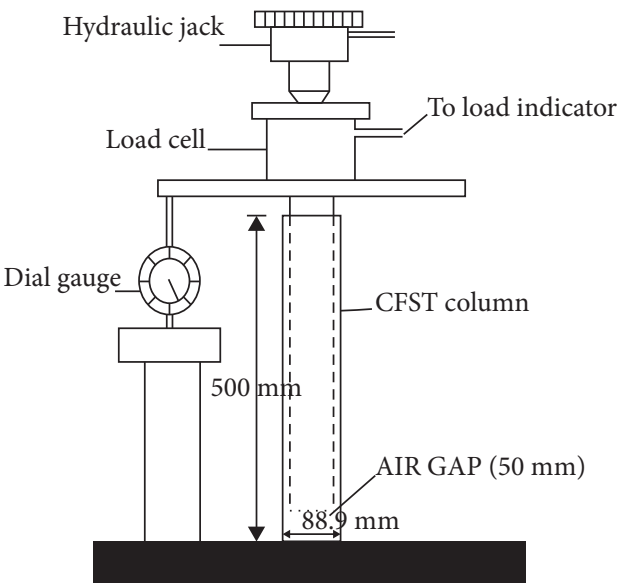

(a)

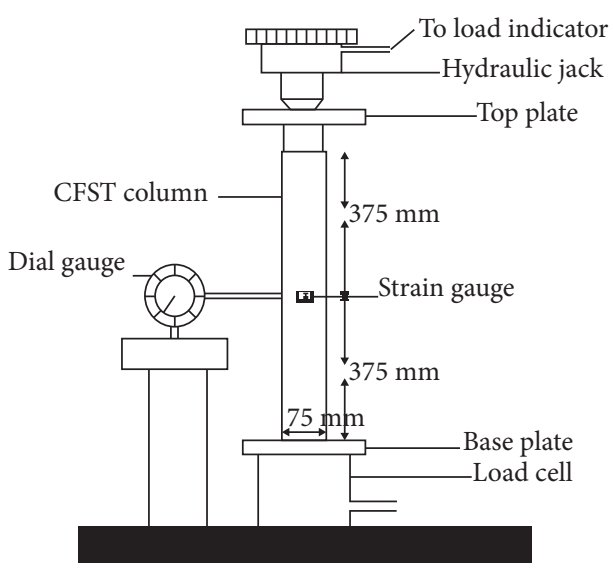

(b)

FIGURE 6: Schematic sketch-test setup for bond strength and axial compression strength.

carrying capacity of various CFST columns are provided in Figures 10 and 11, respectively.

\subsubsection{CFST Columns Infilled with Conventional Concrete} (CCFST). For conventional CFST columns, the failure was detected at an ultimate axial load of $256 \mathrm{kN}$, and the lateral deflection was measured to be $10.6 \mathrm{~mm}$. In the CCFST column specimen, elephant foot buckling occurred at the axial load of $160 \mathrm{kN}$, and a further increase in axial load resulted in failure by overall buckling mode, as shown in
Figure 8. The axial stress at failure was found to be $57.98 \mathrm{MPa}$ with the lateral strain of $2.360 \times 10^{-3}$ as shown in Figure 11 .

4.2.2. CFST Columns Infilled with Steel Fiber-Reinforced Concrete (SCFST). The steel fiber-reinforced concrete-filled steel tube failed at an ultimate axial load of $284 \mathrm{kN}$ with the lateral deflection of $19.7 \mathrm{~mm}$. In the SCFST column specimen, local buckling occurred for an axial load of $120 \mathrm{kN}$, which was initiated close to the top quarter height of the specimen, as shown in Figure 12. The axial stress failure was 


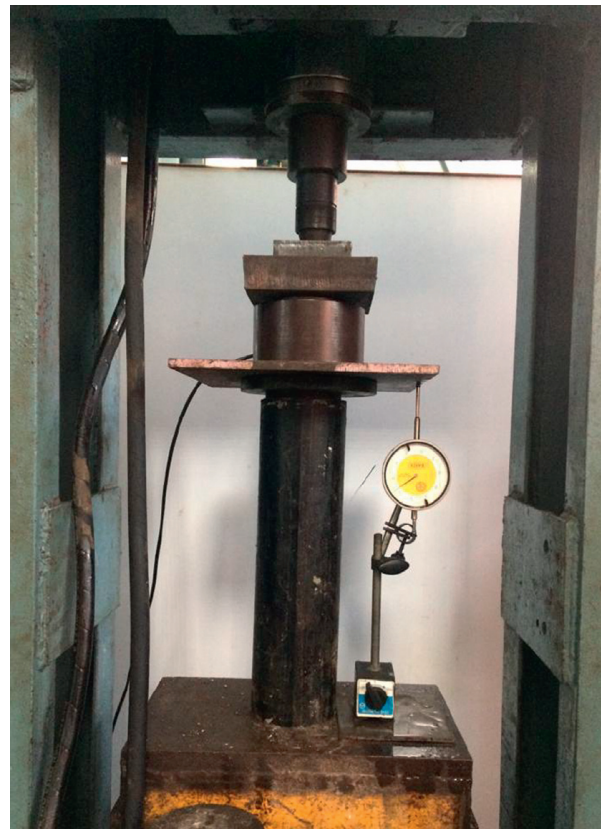

(a)

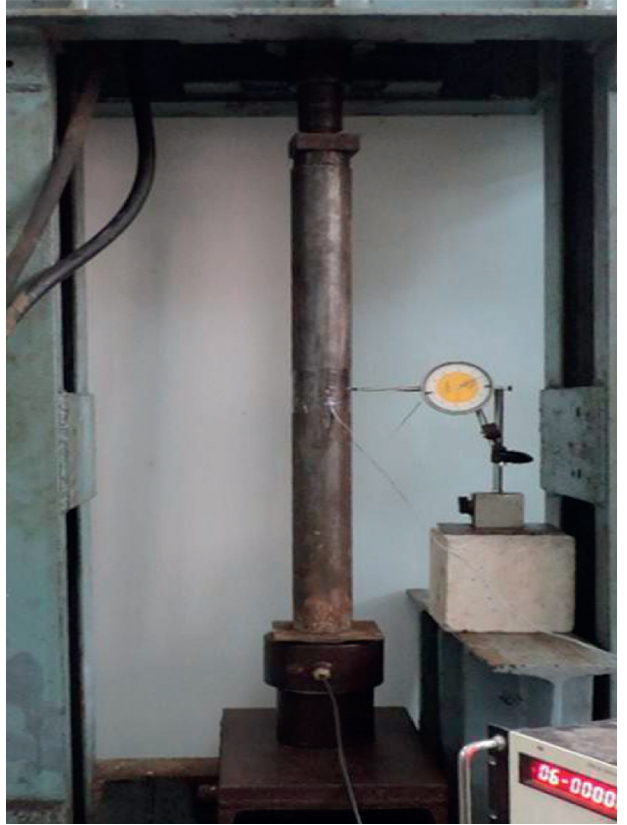

(b)

FIGURE 7: Test setup: push-out test and axial compression test.

TABLE 4: Details of CFST column specimens.

\begin{tabular}{|c|c|c|c|c|c|c|c|}
\hline Test details & $\begin{array}{l}\text { Specimen } \\
\text { ID }\end{array}$ & $\begin{array}{l}\text { Diameter } \\
(\mathrm{mm})\end{array}$ & $\begin{array}{l}\text { Length } \\
(\mathrm{mm})\end{array}$ & $\begin{array}{l}\text { Thickness } \\
(\mathrm{mm})\end{array}$ & $\begin{array}{l}\text { Grade of steel } \\
\qquad(\mathrm{MPa})\end{array}$ & $\begin{array}{c}\text { Grade of } \\
\text { concrete } \\
(\mathrm{MPa})\end{array}$ & $\begin{array}{l}\text { Number of } \\
\text { specimens }\end{array}$ \\
\hline \multirow{4}{*}{ Test for bond strength } & CCFST & 88 & 500 & 4 & 292.5 & 33.68 & 6 \\
\hline & SCFST & 88 & 500 & 4 & 292.5 & 33.89 & 6 \\
\hline & GCFST & 88 & 500 & 4 & 292.5 & 33.89 & 6 \\
\hline & ECFST & 88 & 500 & 4 & 292.5 & 34.70 & 6 \\
\hline \multirow{4}{*}{$\begin{array}{l}\text { Test for load carrying capacity under } \\
\text { axial compression }\end{array}$} & CCFST & 75 & 750 & 1.6 & 281 & 33.68 & 6 \\
\hline & SCFST & 75 & 750 & 1.6 & 281 & 33.89 & 6 \\
\hline & GCFST & 75 & 750 & 1.6 & 281 & 33.89 & 6 \\
\hline & ECFST & 75 & 750 & 1.6 & 281 & 34.70 & 6 \\
\hline
\end{tabular}

CCFST-conventional concrete-filled steel column for bond strength SCFST-steel fiber-reinforced concrete-filled steel column for bond strength; GCFST-geopolymer concrete-filled steel column for bond strength; ECFST-expansive concrete-filled steel column for bond strength.

TABLE 5: Push-out test results.

\begin{tabular}{lccccc}
\hline Specimen ID & Length $(\mathrm{mm})$ & Thickness $(\mathrm{mm})$ & Outer diameter $(\mathrm{mm})$ & Slip at failure $(\mathrm{mm})$ & Ultimate slip load (tonnes) \\
\hline CCFST & 500 & 4 & 88 & 1.2 & 20.25 \\
SCFST & 500 & 4 & 88 & 1.5 & 17.35 \\
GCFST & 500 & 4 & 88 & 2.3 & 22.1 \\
ECFST & 500 & 4 & 88 & 0.8 & 26.8 \\
\hline
\end{tabular}

TABLE 6: CCR under axial compression test.

\begin{tabular}{lccc}
\hline Specimen ID & Axial load at failure $(\mathrm{kN})$ & Lateral deflection at mid-height $(\mathrm{mm})$ & Concrete contribution ratio $(\mathrm{CCR})$ \\
\hline CCFST & 256 & 10.6 & 1.00 \\
SCFST & 284 & 19.7 & 1.11 \\
GCFST & 302 & 15.3 & 1.18 \\
ECFST & 331 & 13.7 & 1.29 \\
\hline
\end{tabular}


TABLE 7: Axial stress vs. lateral strain under axial compression test.

\begin{tabular}{lcr}
\hline Specimen ID & Axial stress at failure $(\mathrm{MPa})$ & ${\text { Lateral strain at mid-height }\left(\times 10^{-3}\right)}$ \\
\hline CCFST & 57.98 & 2.360 \\
SCFST & 64.32 & 3.646 \\
GCFST & 68.39 & 3.310 \\
ECFST & 74.96 & 3.059 \\
\hline
\end{tabular}

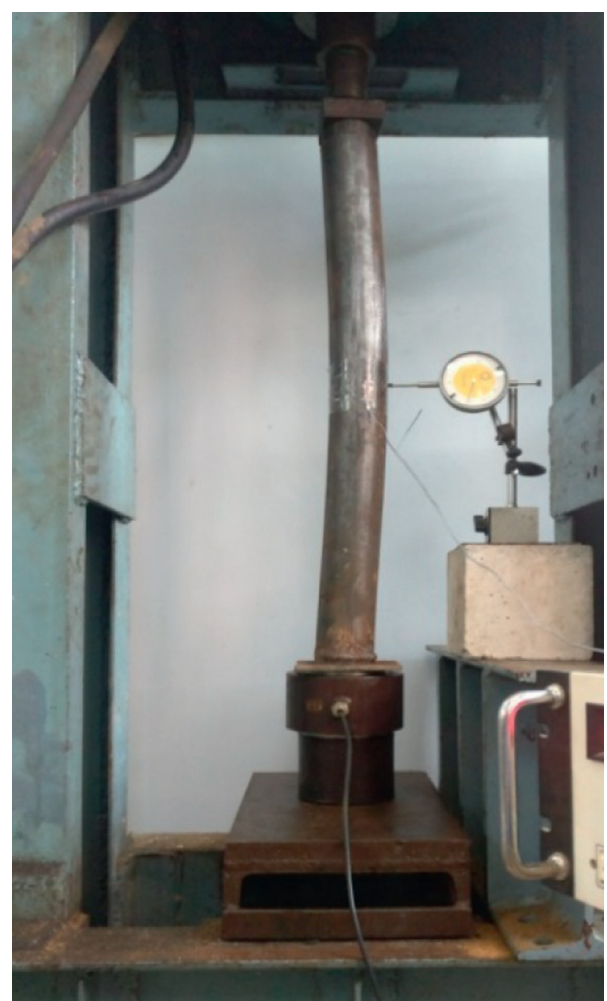

(a)

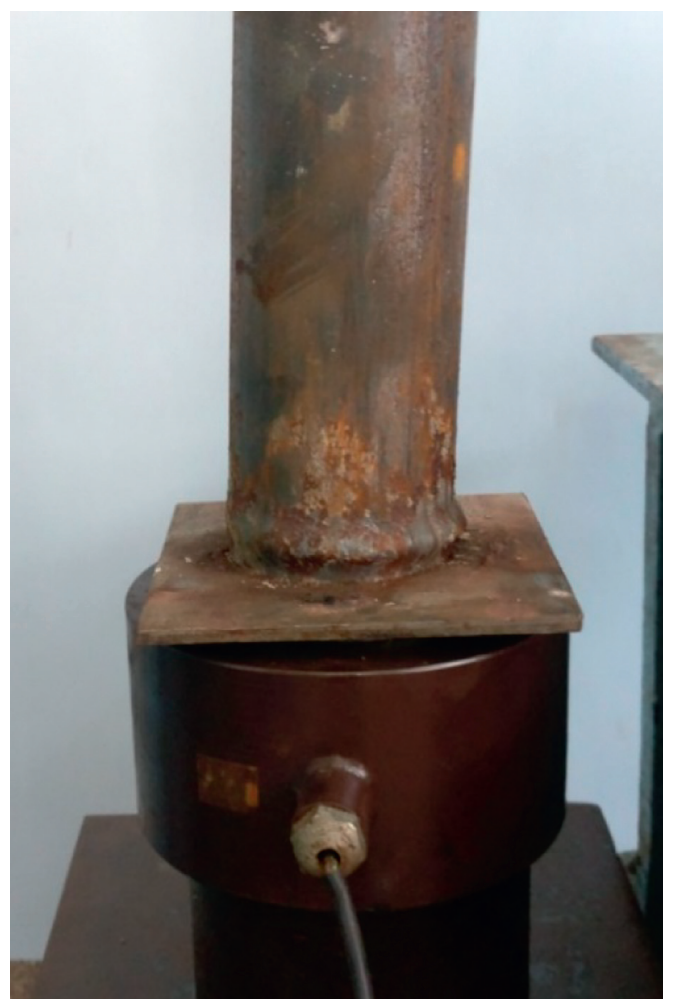

(b)

FIGURE 8: Failure of CCFST specimen under axial compression.

TABle 8: Push-out test results for a constant slip.

\begin{tabular}{lcc}
\hline Specimen ID & Slip (mm) & Slip load (tonnes) \\
\hline CCFST & 0.5 & 13.9 \\
SCFST & 0.5 & 10.2 \\
GCFST & 0.5 & 4.6 \\
ECFST & 0.5 & 21.6 \\
\hline
\end{tabular}

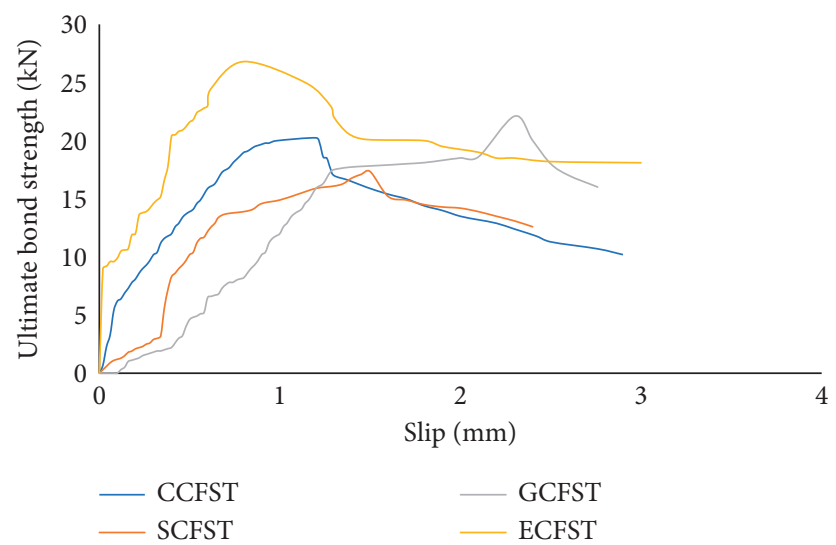

FIgURE 9: Bond strength vs. slip curve. 


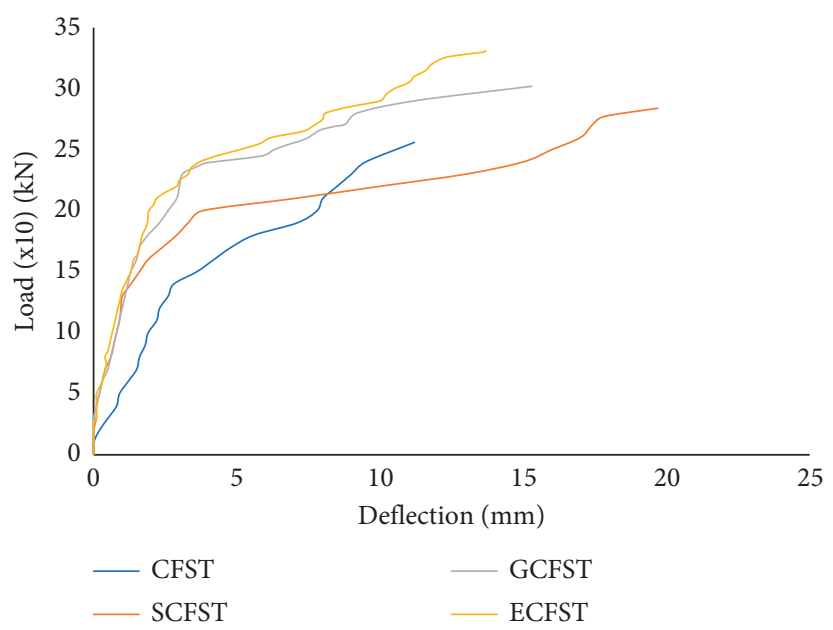

FIgUre 10: Load vs. deflection of CFST columns.

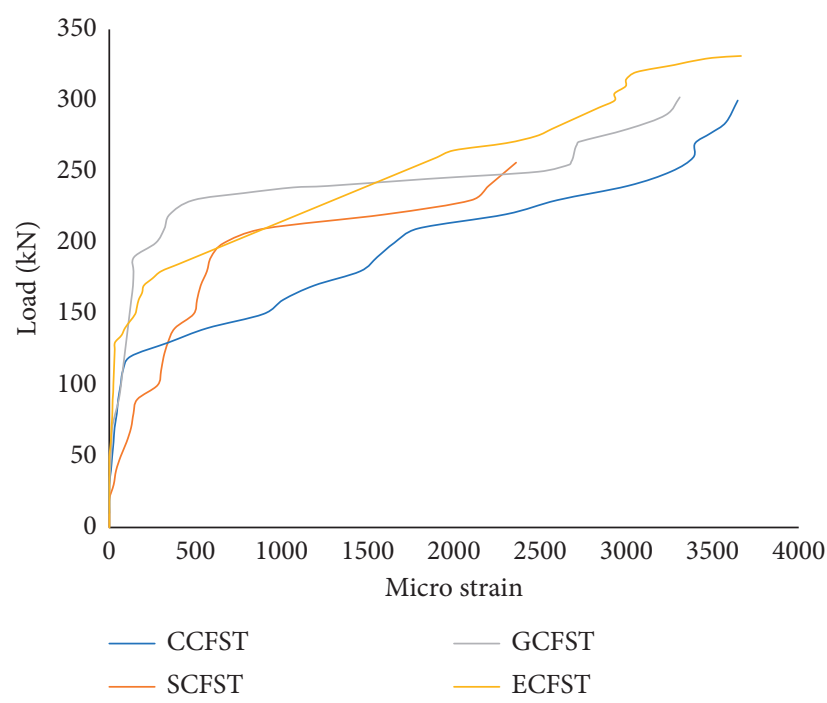

FIgUre 11: Axial load vs. strain curve of CFST columns.

observed with a lateral strain of $3.634 \times 10^{-3}$ for a load of 64.32 $\mathrm{MPa}$ as shown in Figure 11.

4.2.3. CFST Columns Infilled with Geopolymer Concrete (GCFST). The geopolymer concrete-filled steel tube failed at an ultimate axial load of $302 \mathrm{kN}$ with the lateral deflection of $15.3 \mathrm{~mm}$. In the GCFST specimen, local buckling was initiated at an axial load of $136 \mathrm{kN}$, which was observed close to the mid-height of the specimen, as shown in Figure 13. The axial stress at failure was found to be $68.39 \mathrm{MPa}$ with a lateral strain of $3.310 \times 10^{-3}$.

4.2.4. CFST Columns Infilled with Expansive Concrete (ECFST). The expansive concrete-filled steel tube column failed at an ultimate axial load of $331 \mathrm{kN}$ with the lateral deflection of $13.7 \mathrm{~mm}$. In ECFST column specimen, elephant foot buckling occurred at the axial load of $190 \mathrm{kN}$ and with further increase in axial load, and it showed an overall buckling mode of failure as shown in Figure 14. The axial stress at failure was found to be $74.96 \mathrm{MPa}$ with the lateral strain of $3.059 \times 10^{-3}$ as shown in Figure 11 .

4.3. Concrete Contribution Ratio (CCR). CCR is the ratio between axial compressive strength of conventional concrete $\left(N_{u}\right)$ and axial compressive strength of other concretes $\left(N_{\mathrm{dc}}\right)$ and is considered as replacement infill in CFST.

$$
\mathrm{CCR}=\frac{N_{u}}{N_{\mathrm{dcu}}}
$$

The concrete contribution ratios exhibited by different types of infill considered in this study are presented in Table 6.

The axial load at failure, lateral deflection, and CCR under axial compression test are presented in Table 6 and the stress vs. strain under axial compression test is presented in Table 7.

The load vs. deflection graph and axial load carrying capacity of various CFST columns are provided in Figures 10 


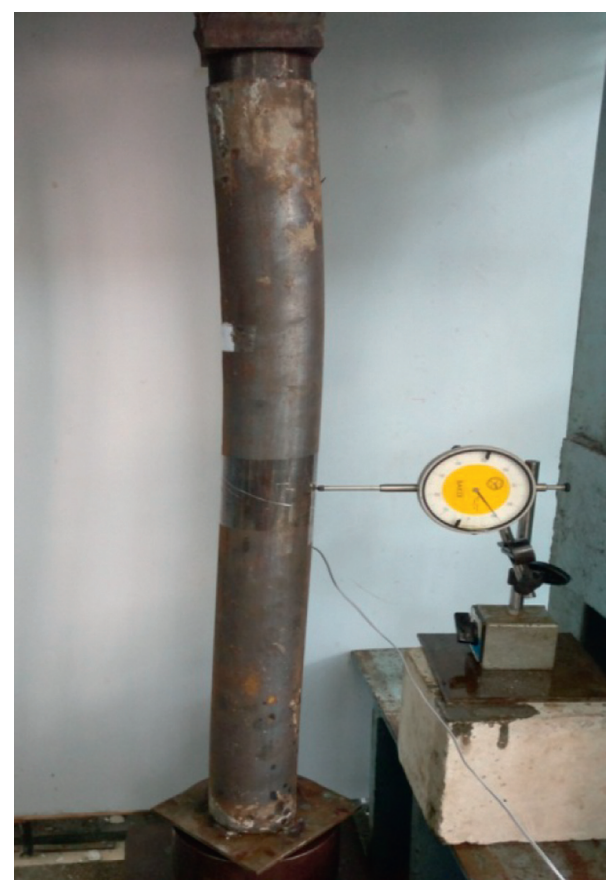

Figure 12: Failure of SCFST specimen under axial compression.

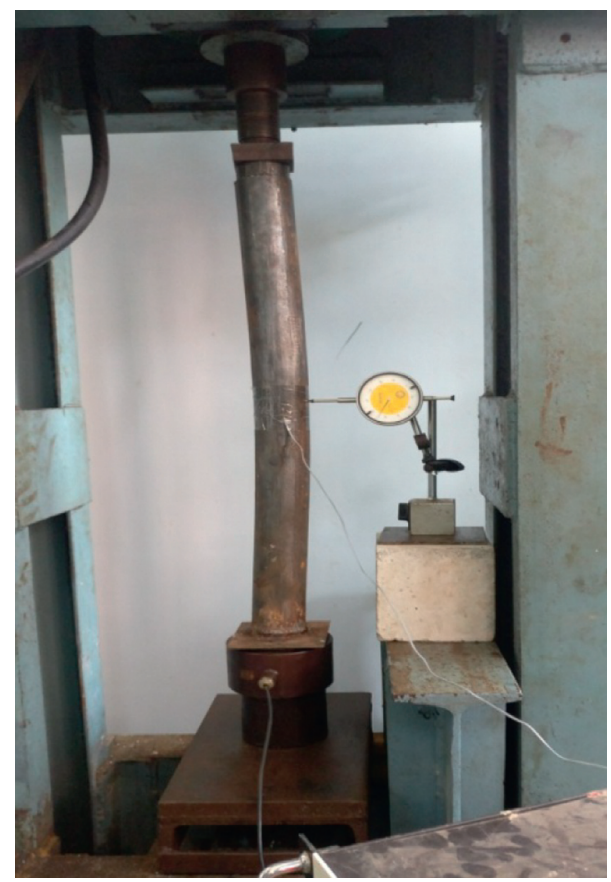

FIGURE 13: Failure of GCFST specimen under axial compression.

and 15, respectively. From Figures 10 and 15, it is inferred that the load carrying capacity of ECFST column is $25.55 \%$, $15.28 \%$, and $9.16 \%$ higher than the CCFST, SCFST, and GCFST columns, respectively.

\subsection{Estimated Axial Load Carrying Capacity Using Eurocode} 4. The axial load carrying capacity for the CFST columns were estimated using Eurocode-4 [17]. Comparison of the estimated values and the experimental results was made. Table 9 shows the observed axial load from experiment, predicted axial load using EC4, and percentage variation between the experimental and predicted values. From Table 7 , it is evident that the theoretical load carrying capacity of ECFST column is $6.16 \%, 3.04 \%$, and $1.29 \%$ higher than the CCFST, SCFST, and GCFST columns, respectively. 


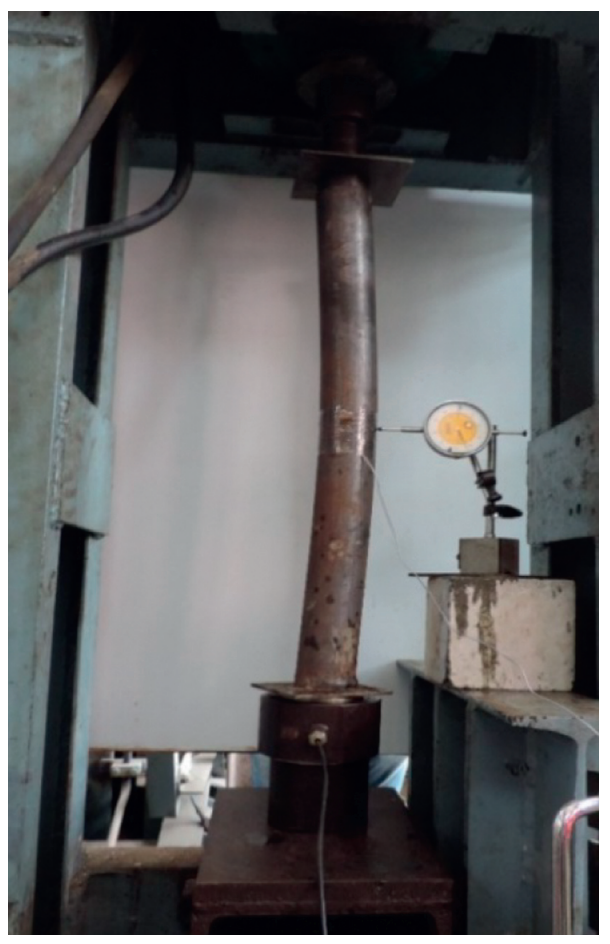

(a)

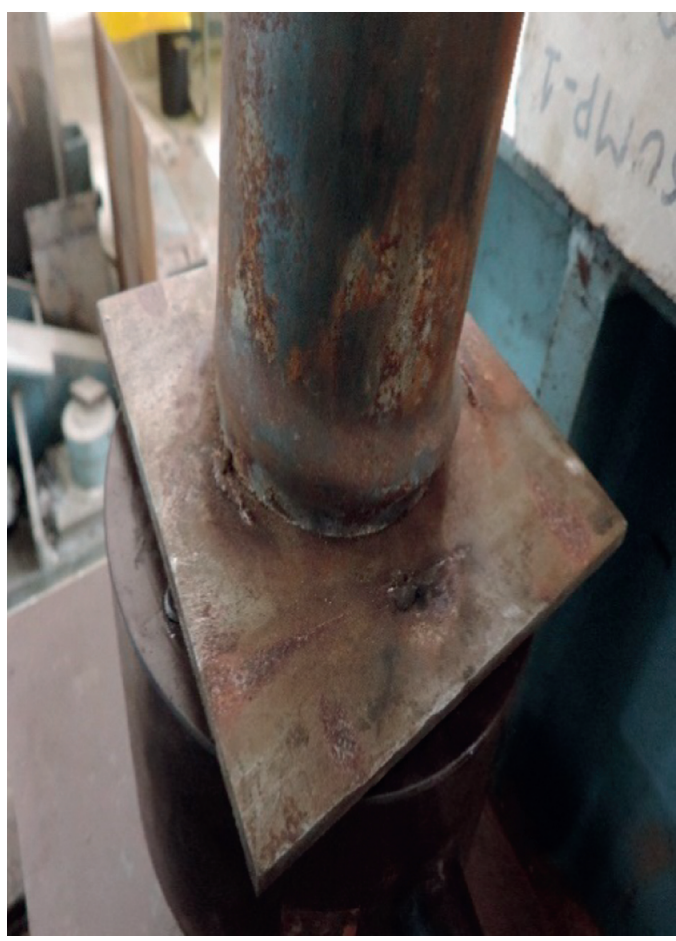

(b)

FIgURE 14: Failure of ECFST specimen under axial compression.

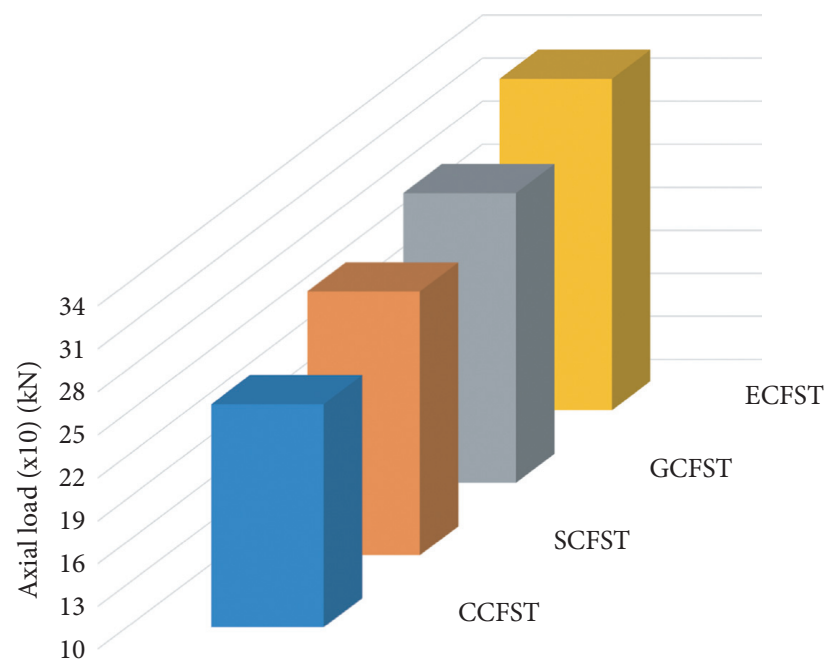

FIgURe 15: Axial load carrying capacity of CFST columns.

TABLE 9: Comparison of test results with predicted EC4 values.

\begin{tabular}{lccc}
\hline Specimen ID & Experimental axial load at failure, $P_{\mathrm{E}}(\mathrm{kN})$ & Analytical axial load at failure, $P_{\mathrm{EC} 4}(\mathrm{kN})$ & $(\%)$ Difference \\
\hline CCFST & 256 & 220 & 16.26 \\
SCFST & 284 & 227 & 25.17 \\
GCFST & 302 & 231 & 30.85 \\
ECFST & 331 & 234 & 41.33 \\
\hline
\end{tabular}




\section{Conclusion}

In this study, the compressive and bond strength behavior of different types of concrete infilled steel tubes were successfully compared and analyzed. The compressive strength of concrete cube specimens cured using a self-curing agent did not show much variation compared with cubes cured with water. The highest bond strength and axial compressive strength were recorded for the CFST column filled with expansive concrete (ECFST). The superior increase in strength of ECFST columns may be attributed to the addition of shrinkage-compensating admixture used in expansive concrete. The values of axial load carrying capacity of CFST column filled with expansive concrete determined through experimental and analytical methods were found to be differing by $41.33 \%$. The observed substantial variation is due to the exclusion of the expansive agent contributions during the analytical calculation. This deviation also indicates the conservative nature of the Eurocode- 4 in the design aspect.

\section{Data Availability}

The data used to support the findings of this study are available from the corresponding author upon request.

\section{Conflicts of Interest}

The authors declare that they have no conflicts of interest.

\section{References}

[1] T. Ekmekyapar and B. J. M. Al-Eliwi, "Experimental behaviour of circular concrete filled steel tube columns and design specifications," Thin-Walled Structures, vol. 105, pp. 220-230, 2016.

[2] L.-H. Han, W. Li, and R. Bjorhovde, "Developments and advanced applications of concrete-filled steel tubular (CFST) structures: members," Journal of Constructional Steel Research, vol. 100, pp. 211-228, 2014.

[3] L.-H. Han, W. Liu, and Y.-F. Yang, "Behaviour of concretefilled steel tubular stub columns subjected to axially local compression," Journal of Constructional Steel Research, vol. 64, no. 4, pp. 377-387, 2008.

[4] L.-H. Han, S.-H. He, and F.-Y. Liao, "Performance and calculations of concrete filled steel tubes (CFST) under axial tension," Journal of Constructional Steel Research, vol. 67, no. 11, pp. 1699-1709, 2011.

[5] Q.-X. Ren, L.-H. Han, D. Lam, and C. Hou, "Experiments on special-shaped CFST stub columns under axial compression," Journal of Constructional Steel Research, vol. 98, pp. 123-133, 2014.

[6] R. Wang, L.-H. Han, and C.-C. Hou, "Behavior of concrete filled steel tubular (CFST) members under lateral impact: experiment and FEA model," Journal of Constructional Steel Research, vol. 80, pp. 188-201, 2013.

[7] Z.-B. Wang, Z. Tao, L.-H. Han, B. Uy, D. Lam, and W.-H. Kang, "Strength, stiffness and ductility of concretefilled steel columns under axial compression," Engineering Structures, vol. 135, pp. 209-221, 2017.

[8] E. M. Güneyisi, A. Gültekin, and K. Mermerdaş, "Ultimate capacity prediction of axially loaded CFST short columns,"
International Journal of Steel Structures, vol. 16, no. 1, pp. 99-114, 2016.

[9] F. Abed, M. AlHamaydeh, and S. Abdalla, "Experimental and numerical investigations of the compressive behavior of concrete filled steel tubes (CFSTs)," Journal of Constructional Steel Research, vol. 80, pp. 429-439, 2013.

[10] Z. Tao, B. Uy, F.-Y. Liao, and L.-H. Han, "Nonlinear analysis of concrete-filled square stainless steel stub columns under axial compression," Journal of Constructional Steel Research, vol. 67, no. 11, pp. 1719-1732, 2011.

[11] Z. Tao, Z.-B. Wang, and Q. Yu, "Finite element modelling of concrete-filled steel stub columns under axial compression," Journal of Constructional Steel Research, vol. 89, pp. 121-131, 2013.

[12] Q.-X. Ren, L.-H. Han, C. Hou, Z. Tao, and S. Li, "Concreteencased CFST columns under combined compression and torsion: experimental investigation," Journal of Constructional Steel Research, vol. 138, pp. 729-741, 2017.

[13] Y. F. Yang and L. H. Han, "Research on bond behavior between steel and concrete of self-compacting concrete filled steel tubes with rectangular sections," Industrial Construction, vol. 36, no. 11, pp. 32-36, 2006.

[14] T. Zhong, Y.-F. Cao, Z. Pan, and M. K. Hassan, "Compressive behaviour of geopolymer concrete-filled steel columns at ambient and elevated temperatures," International Journal of High-Rise Buildings, vol. 7, no. 4, pp. 327-342, 2018.

[15] V. Malagavelli and N. Rao Paturu, "Durability and strength characteristics of fiber reinforced concrete," in Proceedings of the International Conference on Concrete Engineering and Technology 2012 (CONCET2012), Putrajaya, Malaysia, 2012.

[16] IS 10262-2009, Guidelines for Concrete Mix Design Proportioning, Bureau of Indian Standards, New Delhi, India.

[17] European Committee for Standardization, Eurocode 4: "Design of Composite Steel and Concrete Structures - Part 1-1: General rules and rules for buildings", European Union, Brussels, Belgium, 2004. 